\title{
Morphoquantitative Study of Rattus norvegicus Submucosal Plexus by Different Neuronal Evidentiation Histochemical Techniques
}

\author{
Estudio Morfocuantitativo del Plexo Submucoso de Rattus norvegicus por Medio de Diferentes \\ Técnicas Histoquímicas para Verificar Características Neuronales
}

\author{
Marcelo Biondaro Góis*; Catchia Hermes-Uliana**; Alessandra Paltanin ${ }^{* * *}$; Willian Pontes***; Eduardo José De Almeida \\ Araújo $^{* * * *}$; Marcilio Hubner Miranda Neto* \& Débora Mello Gonçales Sant’Ana*
}

GÓIS, M. B.; HERMES-ULIANA, C.; PALTANIN, A.; PONTES, W.; ARAÚJO, E. J. A.; MIRANDA NETO, M. H. \& SANT'ANA, D. M. G. Morphoquantitative study of Rattus norvegicus submucosal plexus by different neuronal evidentiation histochemical techniques. Int. J. Morphol., 34(4):1487-1493, 2016.

SUMMARY: Enteric nervous plexuses have been the object of several studies, specially the myenteric plexus whose studies describe its organization, functions and alterations. On the other hand, the submucosal plexus has been less studied and still needs descriptive studies. To analyze morphologically and quantitatively submucosal neurons of the jejunum of 90-day-old healthy rats using different techniques for neuronal staining as a way to provide normality data to compare with future experimental studies. Whole mount preparations of the jejunum were submitted to Giemsa, NADH-diaphorase and NADPH-diaphorase techniques to stain the total neuronal population, more metabolically active subpopulation and subpopulation of nitrergic neurons, respectively. Neurons of the submucosal plexus of adult rats are mainly organized in ganglia with varied sized and shapes. Giemsa technique stained $243.93 \pm 7.68$ neurons per $\mathrm{mm}^{2}$. Regarding the total population stained by Giemsa, NADH- diaphorase positive $\left(139.09 \pm 11.14 / \mathrm{mm}^{2}\right)$ neurons represented $57 \%$ and NADPH-diaphorase positive $\left(18.17 \pm 0.28 / \mathrm{mm}^{2}\right)$ represented $7.5 \%$. The area of the cell body was bigger in nitrergic neurons $(412.29 \pm 150.22)$ than in the ones stained by Giemsa $(254.71 \pm 63.32)$ and NADH-diaphorase positive $(243.98 \pm 123.82)$.

KEY WORDS: Enteric nervous system, Meissner's plexus; Giemsa, NADH-diaphorase, NADPH-diaphorase.

\section{INTRODUCTION}

The enteric nervous system (ENS) is the third component of the Autonomous Nervous System (ANS) (Langley, 1921) because of its structure and function maintenance in the absence of central nervous system (CNS) efferent neurons (Furness \& Costa, 1987; Furness, 2000; Furness, 2006). This independence is modulated by the signal exchange between ENS and CNS. ENS consists of segments from the upper esophagus until the internal anal sphincter, formed by interconnected meshes: plexuses containing neurons, axons and glial cells. In the intestines, most of the nervous cells form two ganglionated plexus: (Auerbach' s) myenteric plexus located between the longitudinal stratum and the circular muscle layer (Auerbach, 1862 apud Furness, 2006; Alves et al., 2011; Furness, 2012) and the submucosal plexus (Meissner, 1857 apud Furness, 2006; Billroth, 1858 apud Furness, 2006), formerly known as Meissner's plexus, found in the tela submucosa of the large and small intestines (Mckeown et al., 2001; Wood, 2004; Furness, 2006; Grundy et al., 2006).

Detailed reports on the morphology, size and distribution of ganglia of the submucosal plexus are described in the studies by Dogiel (1899) apud Furness (2006), Irwin (1931), Schabadasch (1930) for different species of animals like sheep and cats. These animals were not considered experimental models, therefore, their study was based on the interest in the filogenetic description. Despite the similarity among mammals, it is suggested that the arrangement of the submucosal neurons are species specific (Hoyle \& Burnstock, 1989; Timmermans et al.,

* Universidade Estadual de Maringá. Programa de Pós-graduação em Biologia Comparada. Av. Colombo, 5790, Zona 07, 87020-900, Maringá, PR, Brasil.

** Universidade Federal de Mato Grosso do Sul. Av. Marcio Lima Nantes, sn. Estrada do Pantanal, 79400-000, Coxim, MS, Brasil.

**** Universidade Paranaense. Praça Mascarenhas de Moraes, 4282, Centro, 87502-210, Umuarama, PR, Brasil.

${ }^{* * * * *}$ Universidade Estadual de Londrina, Departamento de Histologia, Centro de Ciências Biológicas. Rodovia Celso Garcia Cid. 86057-970, Londrina, Paraná, Brazil. 
2001) and their description in rodents broadens the possibility of studies on experimental models.

In large mammals, like pigs and humans, submucosal ganglia are interconnected and distributed in two or three levels (Schabadasch; Gunn, 1968; Hoyle \& Burnstock; Timmermans et al.), and the ganglia at different depths have distinct neuronal populations. In small rodents, the submucosal plexus is unique, probably due to the thickness of the submucosal tela (Gunn; Furness \& Costa; Brehmer et al., 2010).

Regarding their function, submucosal neurons are divided into motor neurons, interneurons, intrinsic primary afferent neurons (IPANs) and intrinsic fleeting afferent neurons (IFANs). As to their chemical code, several neurotransmitters have been described like adenosine triphosphate (ATP), nitric oxide (NO), P substance and the vasoactive intestinal peptide (VIP) (Furness, 2006). Through the production and release of neurotransmitters, these neurons coordinate the mucosal secretion, regulate the fluid motility through the intestinal epithelium, change the local blood flow and modulate the inflammatory response interacting with the local immune system (Weber et al., 2001; Neunlist et al., 2003; Toumi et al., 2003; Ekblad \& Bauer, 2004; Furness, 2006; Savidge, 2007).

In the past decades, the myenteric plexus has received special attention and numerous studies have been done to understand its organization, functions and alterations in details. However, the submucosal plexus lacks descriptive studies because it has been less explored concerning its morphofunctional and pathological aspects. Thus, this study aimed to analyze the jejunum submucosal neurons of rats morphometrically and quantitatively with different techniques of neuronal evidentiation as a way to provide normality data for future studies with experimental models.

\section{MATERIAL AND METHOD}

The experimental protocol of this study was previously approved by the Ethics Committee in Research Involving Animal Experimentation (CEPEEA) from Universidade Paranaense (Protocol 12361/2008).

Experimental design. The study used fifteen 90 day-old male Wistar rats (Rattus norvegicus). Rats were submitted to euthanasia in chamber saturated with halothane (Vivas et al., 2007). Necropsia was performed immediately and the jejunum was removed, having the following anatomic limits as reference: duodenojejunal flexure and ileocecal fold. After microdissection, Whole mounts preparations with the submucosal plexus of each animal were obtained and submitted to the Giemsa (Barbosa, 1978), NADH-diaphorase (NADH-d) (Gabella, 1969) and NADPH-diaphorase (NADPH-d) (Scherer-Singler et al., 1983) histochemical techniques to stain the total neuronal population, more metabolically active subpopulation and subpopulation of nitrergic neurons, respectively.

Quantitative analysis of submucosal neurons. For each utilized histochemical technique, the number of ganglia and neurons present in 50 microscopic fields $\left(0.14 \mathrm{~mm}^{2} /\right.$ field $)$ and the number of neurons per ganglion in 50 ganglia were counted. For ganglion counting, an optical microscope Motic BL with 40X lens was used, and the number of stained ganglia varied according to the utilized technique: ganglia with three or more neurons by Giemsa technique, and ganglia with more than two neurons by NADH-diaphorase positive (NADH$\mathrm{d}^{+}$) and NADPH-diaphorase positive (NADPH- $\mathrm{d}^{+}$).

Morphometric analysis of submucosal neurons. For each animal, areas of the cell body and nucleus of 100 neurons were measured by all techniques. The cytoplasm area was calculated from the differences of these areas. Besides, the ratio between the nucleus area and the cell body area was determined to verify the rate occupied by this organelle inside the neuron. From the calculation of the cell body area of neurons stained by different techniques, it was possible to divide them in groups. The measurement was done using a photonic microscope with a 100X lens coupled to the image analysis system Motic Images Plus, version 2.0.

\section{RESULTS}

The submucosal plexus is a continuous structure along the intestinal circumference, organized in a single plan. In this plexus, numerous isolated neurons are found (Fig. 1 $a, b, c)$ predominantly neurons grouped in ganglia of different shapes (Fig. 1 d, e, f).

The number of neurons and ganglia per $\mathrm{mm}^{2}$, the number of neurons per ganglia, and the mean profile areas of cell bodies, cytoplasm and nuclei as well as the nucleus / cell body ratio of the neurons stained by each utilized technique can be verified in Table I.

Regarding morphology, neurons with rounded, oval and elliptical bodies were observed and most of them presented an eccentric nucleus.

Figure 2 shows the neuron distribution per group considering the profile areas of the cell body as basis. 
Table I. Population density and morphometric analysis of the jejunum submucosal plexus neurons of rats stained with Giemsa, NADH-d+ and NADPH-d+.

\begin{tabular}{|c|c|c|c|}
\hline Measures & GIEMSA & NADH-d $^{+}$ & NADPH-d ${ }^{+}$ \\
\hline Neurons/mm ${ }^{2}$ & $243.93 \pm 7.68$ & $139.09 \pm 11.14$ & $18.17 \pm 0.28$ \\
\hline Ganglia/mm ${ }^{2}$ & $19.21 \pm 0.99$ & $25.54 \pm 3.03$ & $6.48 \pm 0.33$ \\
\hline Neurons/ganglion & $11.40 \pm 0.22$ & $5.36 \pm 0.63$ & $2.80 \pm 0.10$ \\
\hline Cell body ( $\left.\mu \mathrm{m}^{2}\right)$ & $254.71 \pm 63.32$ & $243.98 \pm 123.82$ & $412.29 \pm 150.22$ \\
\hline Cytoplasm $\left(\mu \mathrm{m}^{3}\right)$ & $138.53 \pm 21.83$ & $189.31 \pm 26.25$ & $302.20 \pm 101.46$ \\
\hline Nucleus $(\mu \mathrm{m} 3)$ & $110.44 \pm 11.41$ & $54.77 \pm 12.36$ & $110.14 \pm 35.52$ \\
\hline Nucleus/Cell body & $0.44 \pm 0.01$ & $0.24 \pm 0.06$ & $0.40 \pm 0.16$ \\
\hline
\end{tabular}

Values were expressed by mean \pm standard error
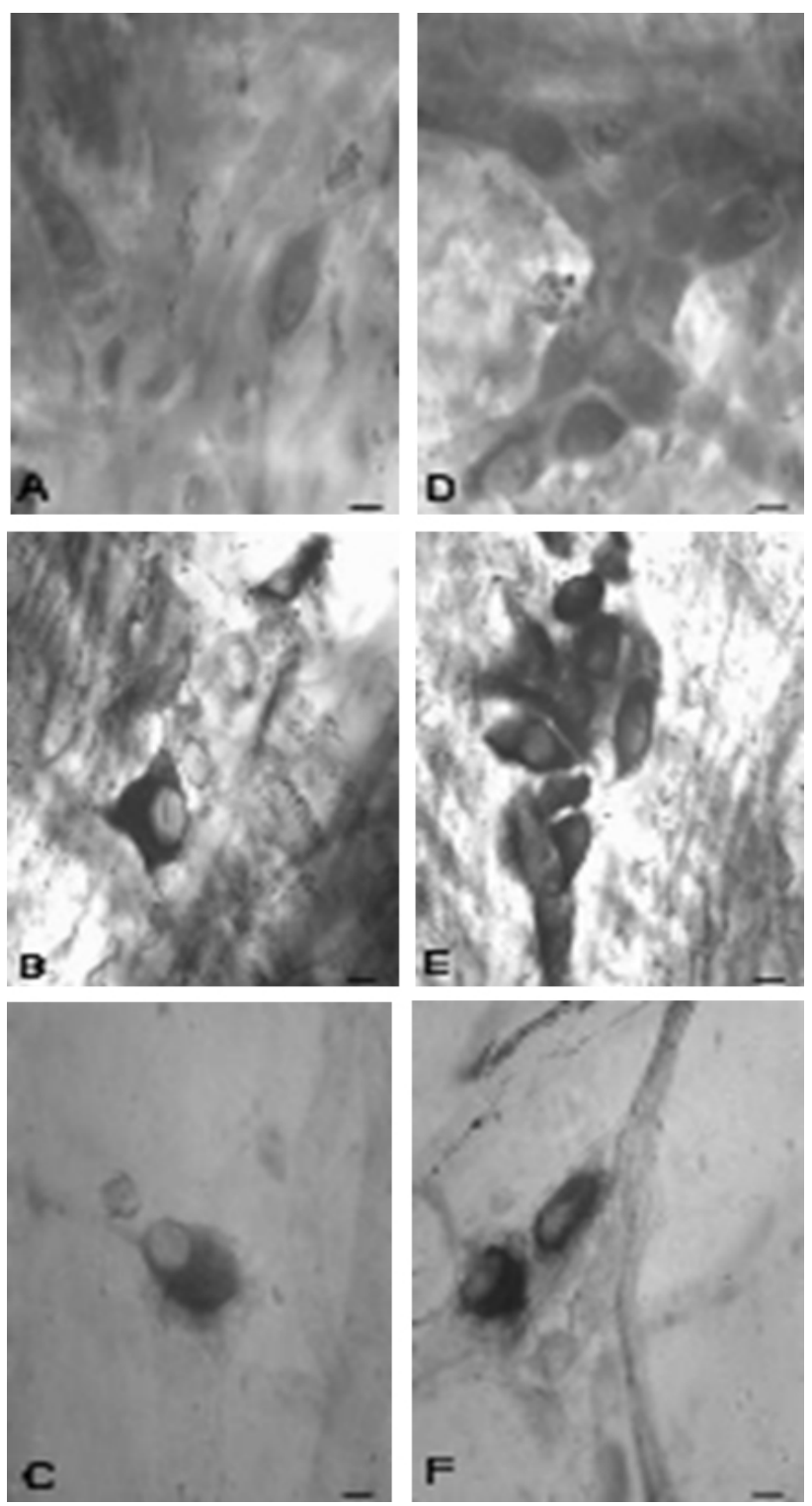

Fig. 1. Photomicrographs of isolated submucosal neurons (a, b and c) and in jejunum submucosal plexus ganglia (d, e and f) of adult rat stained by Giemsa (a and d), NADH- $\mathrm{d}^{+}(\mathrm{b}$ and e) and $\mathrm{NADPH}-\mathrm{d}^{+}$(c and f) techniques. Fifty $\mu \mathrm{m}$ bar.

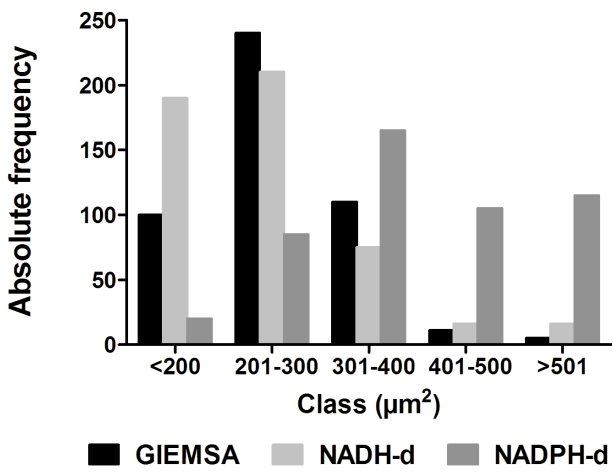

Fig. 2. Distribution of neurons stained by Giemsa, $\mathrm{NADH}-\mathrm{d}+$ and NADPH- $\mathrm{N}+$ techniques in different groups according to the cell body area.

\section{DISCUSSION}

In this experiment, the submucosal plexus was observed as a continuous structure along the intestinal circumference, organized in a single plan. These characteristics were also observed in small mammals whose submucosal plexus is unique due to the smaller thickness of the submucosal tela (Gunn; Furness, 2006; Brehmer et al.). Authors that have studied large mammals like apes, swine and human beings found the submucosal plexus divided in two or more smaller plexuses (Gunn; Hoyle \& Burnstock; Furness and Costa; Brehmer et al.), mainly an internal submucosal plexus and an external one. Generally one is found in the basis of the mucosal tunica towards the structures located there and the other is seen inside the submucosal tela, enervating glands (Gunn; Balemba et al., 1998; Furness, 2006; Brehmer et al.).

From the neuronal evidentiation techniques utilized in this study, it can be noticed that the neurons of the submucosal plexus organize themselves into interconnected ganglia through fiber bundles. However, isolated neurons were observed in smaller number. The predominance of neurons organized in ganglia was also observed in submucosal tela of rats' ileum (Buttow et al., 2004) and other species (Sousa, 1994; Zanesco \& Souza, 2011).

When the number and the size of stained ganglia were evaluated, it was verified that the ganglia stained by Giemsa were visibly bigger, gathering an average of twice the number of neurons than in ganglia stained by NADH$\mathrm{d}^{+}$and about five times more than nitrergic neurons. However, when quantitative data were considered together, it was observed that most NADH-d+ and NADPH-d+ 
GÓIS, M. B.; HERMES-UliANA, C.; PALTANIN, A.; PONTES, W.; ARAÚJO, E. J. A.; MIRANDA NETO, M. H. \& SANT'ANA, D. M. G. Morphoquantitative study of Rattus norvegicus submucosal plexus by different neuronal evidentiation histochemical techniques. Int. J. Morphol., 34(4):1487-1493, 2016.

neurons were isolated. These findings may represent really isolated neurons in nervous fiber bundles and also neurons present in ganglia where most of the neurons were not stained by these techniques, except by Giemsa technique, because of their functional and biochemical characteristics.

Using Giemsa technique, it was verified that in the jejunum submucosal plexus of rats, ganglia had from 4 to 20 neurons (an average of 11.4 per ganglion). Our findings are similar to the ones by Zanesco \& Souza that described submucosal ganglia stained by Giemsa technique and that were formed by one to 30 neurons, an average of nine neurons per ganglion, in guinea pigs" "jejunum-ileum". On the other hand, the number of neurons/ganglion observed by myosin V staining in the ileum submucosal tela of rats has an average of 4.79 (Buttow et al.). The number of neurons stained by Giemsa technique in this study (243 neurons $/ \mathrm{mm}^{2}$ ) is significantly greater than the one found by immune histochemical technique for myosin $\mathrm{V}\left(94.12\right.$ neurons $\left./ \mathrm{mm}^{2}\right)$ in the ileum submucosal tela of rats (Buttow et al.). These differences can be related to the differences of neuronal density between the segments of each study, and also to the fact that not all myenteric neurons are myosin $\mathrm{V}$ positive while polyribosomes of all neurons are stained by Giemsa technique. Marese et al. (2007), when comparing the average number of duodenum myenteric neurons of rats at 21 days and at 428 days using non-histochemical Giemsa technique and immune histochemical technique for myosin $\mathrm{V}$, verified a neuronal reduction of $85.4 \%$ and $82.7 \%$, respectively, for both techniques. However, the comparison of ganglion number/ $\mathrm{mm}^{2}$ did not show a difference between this study and the one by Buttow et al. Souza (1994) demonstrated that in the submucosal plexus of the wild rodent Calomys callosus there are ganglia of several sizes formed by NADH- $\mathrm{d}^{+}$ neurons. They also report observing isolated cells or paired cells among the ganglia.

A greater density of submucosal neurons was verified by Giemsa technique that can be considered a panneuronal technique because it stains neurons due to the affinity of the stain with structures formed by acid proteins, especially polyribosomes. Based on the staining of enteric neurons by Giemsa technique (Barbosa), they classify neurons according to the cytoplasm basophilia and state that this technique allows to visualize polyribosome disintegration (Nissl' corpuscles) in the neuronal chromatolysis processes (Sant`Ana et al., 1997).

$\mathrm{NADH}-\mathrm{d}^{+}$neurons represented $57 \%$ of the total population. This technique must be chosen when it is intended to evidentiate more active neurons metabolically because of the formation of formazan granules as a result of the reaction of $\mathrm{H}+$ ions from the respiratory chain with an artificial electron acceptor - Nitroblue Tetrazolium (NBT) catalyzed by the mitochondrial enzyme NADH-d. It is essential to establish an experimental protocol in which the exposure time (reaction) and the ambient temperature are controlled and standardized. Our study group adopts 45 minutes as standard time (Sant'Ana et al., 1997) because longer exposure times may stain lower metabolism neurons and other cells.

NADPH- $\mathrm{d}^{+}$neurons stained in this experiment correspond to nitrergic neurons because NADPHdiaphorase and NOS (Nitric Oxide Synthase) neurons are co-located, according to Belai et al. (1992). Several authors showed this correspondence between them, (SchererSingler et al.; Santer et al., 1994) to name a few, indicating that NADPH- $\mathrm{d}^{+}$histochemical can be used as a nitrergic neuron marker.

In this study with 90-day-old rats, a small rate of nitrergic neurons was found (7.5\% of the total population). In adult mice, Young \& Ciampoli (1998) estimated that the nitrergic neuron population was $3 \%$. However, studies on jejunum (Hermes-Uliana et al., 2014) and duodenum (Lopes et al., 2012) of 210-day-old rats found $26 \%$ and $23 \%$ of nitrergic neurons in the submucosal plexus, respectively. A greater density of $\mathrm{NADPH}-\mathrm{d}^{+}$neurons and a greater expression of NOS in aging process rats was verified by several authors that have related this finding to a greater resistance of these neurons to nutritional deficiencies (Sant'Ana et al., 2012a), degenerative processes caused by aging and by chronic degenerative diseases (Fregonesi et al., 2004), and NOS expression by neurons that did not use to express it but start doing it when initiating the cell death process (Fregonesi et al.). A greater density of nitrergic neurons was also related to a greater relaxation of smooth musculature (Hermes-Uliana et al.).

Enteric neurons can also be evidentiated by silver staining (Irwin), acetylcholinesterase (Gunn), immune staining of substance P (SP), tachykinin (NK), calcitonin gene related peptide (CGRP) (Mitsui, 2010), vasoactive intestinal peptide (VIP) (Hernandes et al., 2004; Sant' Ana et al., 2012b), nitric oxide synthase (NOS), Calretinin (Sayegh \& Ritter, 2003), myosin V (Buttow et al.; Marese et al.) among others. It is important to point out that when adopting a staining technique, researchers have to clearly remember which variables they want to study and not only worry about verifying if the technique stains all neurons; for example, neurons that were immune reactive to SP represented $11 \%$ and NK $73 \%$ of total submucosal population of rats' colon (Mitsui). 
GÓIS, M. B.; HERMES-UlianA, C.; PALTANIN, A.; PONTES, W.; ARAÚJO, E. J. A.; MIRANDA NETO, M. H. \& SANT'ANA, D. M. G. Morphoquantitative study of Rattus norvegicus submucosal plexus by different neuronal evidentiation histochemical techniques. Int. J. Morphol., 34(4):1487-1493, 2016.

The submucosal neurons described in this study have presented varied sizes and distinct shapes like triangular, oval, polygonal and elongated, similar to the ones found in rodents like guinea pigs (Zanesco \& Souza) and Calomys callosus (Sousa). The contraction of the intestinal smooth musculature causes alterations in the ganglion shape and, therefore, when evaluating the shape and density, the contractile status of the intestinal wall should be taken into consideration (Gabella, 1971). Mitsui verified that neurons of the colon submucosal plexus of rats also presented round and oval cell bodies. In general, when compared to what Gunn observed in the submucosal plexus of different species of mammals stained by silver, there was homogeneity in the shapes of the neuron cell bodies.

Through histochemical of NADPH-d, it was also possible to verify the beginning of cytoplasm extensions of neurons which emerges from the opposing pole to the nucleus with characteristics of unipolar neurons. However, new studies are necessary utilizing techniques that better stain the extensions so that they can be classified according to the different types of Dogiel.

When observing the average cell body area of submucosal neurons, it can be noticed that NADPH- $\mathrm{d}^{+}$ neurons are the largest cells with larger cytoplasm areas than the others. On the other hand, NADH- $\mathrm{d}^{+}$and the total population of neurons is composed by $250 \mu \mathrm{m}^{2}$ cell body neurons, similar to what was observed in the ileum submucosal neurons of rats, stained by immune histochemical of myosin V (Buttow et al.). Utilizing Giemsa and myosin V techniques, Marese et al. described two patterns of neuronal body profiles. Neurons with areas smaller than $200 \mu \mathrm{m}^{2}$ were predominant in young rats (21 to 60 days of age) whereas neurons with area of 200-600 $\mu \mathrm{m}^{2}$ were predominant in adult animals. Similar results were described by Gabella (1971), who analyzed the relationship between the size of the neuronal cell body of the small intestine myenteric plexus by means of NADPH- $\mathrm{d}^{+}$histochemical and development period of albino neonatal rats and adult rats (Epimys norvegicus). The author concluded that while growing there was an augmentation of the neuronal size, and the predominant population in neonatal animals was small neurons. In wild rodents Calomys callosus Sousa found that the average size of $\mathrm{NADH}-\mathrm{d}^{+}$neurons in the jejunum was $156 \mu \mathrm{m}^{2}$.

When observing Figure 2, it can be noticed that NADH$d+$ neurons are concentrated in smaller classes $(<200$ and 201$300 \mu^{2}$ ), therefore, when compared to others, they are smaller. On the other hand, NADPH- $\mathrm{d}^{+}$neurons are bigger because their distribution slides to the right in Figure 2. These cells are concentrated in classes over $301 \mu \mathrm{m}^{2}$. When evaluating the total neuronal population, stained by Giemsa, the tendency decreases and the area occupies a more central position with intermediary cell body sizes.

It was verified that $\mathrm{NADH}-\mathrm{d}^{+}$neurons had smaller nuclear areas in which the nucleus occupied only $24 \%$ of the cell body area. It is believed that these neurons possibly have a more developed synthesis mechanism which would contribute to a larger cytoplasm area, because these cells have more active metabolism. Studies on the ultrastructure are necessary to stain the subcellular components of this neuronal population.

Knowing the shape and area of the cell body, nucleus position and area, as well as the proportion of the cell body and the nucleus is important because they reflect the functional state of the neurons. These parameters may undergo alterations caused by intra and intercellular disorders, for example, in the apoptosis processes in which the neuron nucleus shows several condensation and aggregation stages of chromatin and disproportionally becomes small "pyknotic nuclei" (Danial \& Korsmeyer, 2004; Kumar et al., 2008). On the other hand, it is important to point out that the peripheral positioning of the nucleus is normal in ENS, while it indicates axonal lesion in CNS and is generally followed by central chromatolysis (Kumar et al.).

Studies involving neurons and fibers of the submucosal plexus are promising because of their involvement in the maintenance of the intestinal mucosal structure. These neurons detect variations of the intestinal lumen and in the mucosal homeostasis, presenting specific receptors for serotonin (5-HT) secreted by enterochromaphin cells of the mucosa, and performing an important role in ENS afference (Michel et al., 2005).

\section{CONCLUSION}

Thus, it is concluded that in the jejunum submucosal plexus of adult rats:

1. a lot of isolated neurons are found, but the predominant organization is ganglia with various sizes and shapes.

2 . Giemsa technique stains the total neuronal population, $\left(243.93 \pm 7.68\right.$ neurons $\left./ \mathrm{mm}^{2}\right)$ where NADH- $\mathrm{d}^{+}$neurons represent $57 \%$ and NADPH- $\mathrm{d}^{+}$neurons represent $7.5 \%$ of total population.

3. The average cellular body areas of NADPH-d+ neurons are bigger than the average od the cellular bodies stained by Giemsa and NADH-d ${ }^{+}$.

ACKNOWLEDGMENTS. The authors thank Conselho Nacional de Desenvolvimento Científico e Tecnológico (CNPq) for the financial support. 
GÓIS, M. B.; HermeS-UlianA, C.; PALTANin, A.; PONTES, W.; ARAÚJO, E. J. A.; MiRANDA NETO, M. H. \& SANT’ANA, D. M. G. Estudio morfocuantitativo del plexo submucoso de Rattus norvegicus por medio de diferentes técnicas histoquímicas para verificar características neuronales. Int. J. Morphol., 34(4):1487-1493, 2016.

RESUMEN: El plexo nervioso entérico ha sido objeto de varios estudios, especialmente el plexo mientérico, cuyos estudios consisten en describir su organización, funciones y alteraciones. Por otro lado, el plexo submucoso ha sido menos investigado y todavía necesita estudios descriptivos. Para analizar morfológica y cuantitativamente las neuronas de la submucosa del yeyuno de ratas de 90 días de edad, se realizaron diferentes técnicas de tinción neuronales, en animales sanos, como una forma de proporcionar datos de normalidad y compararlo con futuros estudios experimentales. Se realizaron montajes con preparados enteros del yeyuno que fueron sometidos a las técnicas de Giemsa, de NADPH-diaforasa y NADH-diaforasa para teñir la población total neuronal, subpoblación más activa metabólicamente y subpoblación de neuronas nitrérgicas, respectivamente. Las neuronas del plexo submucoso de ratas adultas se organizan principalmente en los ganglios con variaciones de tamaño y formas. Con la técnica de Giemsa se tiñeron $243.93 \pm 7.68$ neuronas por mm². Con respecto a la población total teñida con Giemsa, fueron positivas para NADH- diaforasa en $139.09 \pm 11.14 / \mathrm{mm}^{2}$ neuronas, representando el $57 \%$ y fueron positivas para NADPH-diaforasa en 18,17 $\pm 0,28 / \mathrm{mm}^{2}$ neuronas, lo que representó el 7,5\%. El área del cuerpo celular fue mayor en neuronas nitrérgicas $(412,29 \pm 150.22)$ que en las teñidas con Giemsa $(254,71 \pm 63,32)$ y NADH-diaforasa positivas $(243,98 \pm 123,82)$.

PALABRAS CLAVE: Sistema nervioso entérico; Plexo de Meissner; Giemsa; NADH-diaforasa; NADPH-diaforasa.

\section{REFERENCES}

Auerbach, L. Ueber einen Plexus gangliosus myogastricus. Jahres-Bericht Abh Schlesischen Gesells Vaterland Cult. 39:103-4, 1862. In: Furness, J. B. The enteric nervous system. Malden, Blackwell Publishing, 2006.

Alves, M. S.; Silva, A. V.; Bianchi, L. R. O.; Araújo, E. J. A. \& Sant'Ana, D. M. G. Toxoplasma gondii induces death of gastric myenteric neurons in rats. Int. J. Morphol., 29(1):293-8, 2011.

Balemba, O. B.; Grøndahl, M. L.; Mbassa, G. K.; Semuguruka, W. D.; Hay-Smith, A.; Skadhauge, E. \& Dantzer, V. The organisation of the enteric nervous system in the submucous and mucous layers of the small intestine of the pig studied by VIP and neurofilament protein immunohistochemistry. J. Anat., 192(Pt. 2):257-67, 1998.

Barbosa, A. J. A. Técnica histológica para gânglios nervosos intramurais em preparados espessos. Rev. Bras. Pesqui. Med. Biol., 11:95-7, 1978.

Belai, A.; Schmidt, H. H.; Hoyle, C. H.; Hassall, C. J.; Saffrey, M. J.; Moss, J.; Förstermann, U.; Murad, F. \& Burnstock, B. Colocalization of nitric oxide synthase and NADPH-diaphorase in the myenteric plexus of the rat gut. Neurosci. Lett., 143(1-2):60-4, 1992.

Billroth, T. Einige Beobachtungen uber das ausgedehnte Vorkommen von Nerven anastomosen im Tractus Intestinalis. Archive of Anatomy and Physiology of Leipzig, 148-58, 1858. In: Furness, J. B. The enteric nervous system. Malden, Blackwell Publishing, 2006.

Brehmer, A.; Rupprecht, H. \& Neuhuber, W. Two submucosal nerve plexus in human intestines. Histochem. Cell Biol., 133(2):149-61, 2010.

Buttow, N. C.; Santin, M.; Macedo, L. C.; Neres Teixeira, A. C.; Novakowski, G. C.; Bolonheis Armelin, T. R. \& Assmann, K. Study of the myenteric and submucous plexuses after BAC treatment in the intestine of rats. Biocell, 28(2):135-42, 2004.

Danial, N. N. \& Korsmeyer, S. J. Cell death: critical control points. Cell, 116(2):205-19, 2004.

Dogiel, A. S. Uber den Bau der Ganglien in den Gefl echten des Darmes und der Gallenblase des Menschen und der Sauge Saugetiere. Archi- ve of Anatomy and Physiology of Leipzig, 130-58, 1899. In: Furness, J. B. The enteric nervous system. Malden, Blackwell Publishing, 2006.

Ekblad, E. \& Bauer, A. J. Role of vasoactive intestinal peptide and inflammatory mediators in enteric neuronal plasticity. Neurogastroenterol. Motil., 16 Suppl. 1:123-8, 2004.

Fregonesi, C. E. P. T.; Molinari, S. L. \& Miranda Neto, M. H. Avaliacão da populacão de neuronios mioentéricos NADPH- diaforase positivos do corpo do estomago de ratos com diabetes cronico induzido pela estreptozootocina. Acta Scientiarum Biol. Sci., 26(1):107-12, 2004.

Furness, J. B. \& Costa, M. The Enteric Nervous System. Edinburgh, Churchill Livingstone, 1987.

Furness, J. B. Types of neurons in the enteric nervous system. J. Auton. Nerv. Syst., 81(1-3):87-96, 2000.

Furness, J. B. The Enteric Nervous System. Malden, Blackwell Publishing, 2006.

Furness, J. B. The enteric nervous system and neurogastroenterology. Nat. Rev. Gastroenterol. Hepatol., 9(5):286-94, 2012.

Gabella, G. Detection of nerve cells by a histochemical technique. Experientia, 25(2):218-9, 1969.

Gabella, G. Neuron size and number in the myenteric plexus of the newborn and adult rat. J. Anat., 109(Pt. 1):81-95, 1971.

Grundy, D.; Al-Chaer, E. D.; Aziz, Q.; Collins, S. M.; Ke, M.; Taché, Y. \& Wood, J. D. Fundamentals of neurogastroenterology: basic science. Gastroenterology, 130(5):1391-411, 2006.

Gunn, M. Histological and histochemical observations on the myenteric and submucous plexuses of mammals. J. Anat., 102(Pt. 2):223-39, 1968.

Hermes-Uliana, C.; Panizzon, C. P.; Trevizan, A. R.; Sehaber, C. C.; Ramalho, F. V.; Martins, H. A. \& Zanoni, J. N. Is L-glutathione more 
effective than L-glutamine in preventing enteric diabetic neuropathy? Dig. Dis. Sci., 59(5):937-48, 2014.

Hernandes, L.; Gama, P. \& Alvares, E. P. Ileal VIP submucous neurons: confocal study of the area enlargement induced by myenteric denervation in weanling rats. Regul. Pept., 117(1):69-72, 2004.

Hoyle, C. H. \& Burnstock, G. Neuronal populations in the submucous plexus of the human colon. J. Anat., 166:7-22, 1989.

Irwin, D. A. The anatomy of Auerbach's plexus. Am. J. Anat., 49(1):141-66, 1931.

Kumar, V.; Abbas, A. K.; Fausto, N. \& Mitchell, R. N. Robbins. Patología Básica. Philadelphia, W. B. Saunders, 2008.

Langley, J. N. The Autonomic Nervous System. Cambridge, W. Heffer \& Sons, 1921.

Lopes, C. R.; Ferreira, P. E.; Zanoni, J. N.; Alves, A. M.; Alves, E. P. \& Buttow, N. C. Neuroprotective effect of quercetin on the duodenum enteric nervous system of streptozotocin-induced diabetic rats. Dig. Dis. Sci., 57(12):310615, 2012.

Marese, A. C.; de Freitas, P. \& Natali, M. R. Alterations of the number and the profile of myenteric neurons of Wistar rats promoted by age. Auton. Neurosci., 137(1-2):10-8, 2007.

McKeown, S. J.; Chow, C. W. \& Young, H. M. Development of the submucous plexus in the large intestine of the mouse. Cell Tissue Res., 303(2):301-5, 2001.

Meissner, G. Uber die Nerven der Darmwand. Z Ration Med N F 8: 364-366, 1857. In: Furness, J. B. The enteric nervous system. Malden, Blackwell Publishing, 2006.

Michel, K.; Zeller, F.; Langer, R.; Nekarda, H.; Kruger, D.; Dover, T. J.; Brady, C. A.; Barnes, N. M. \& Schemann, M. Serotonin excites neurons in the human submucous plexus via 5-HT3 receptors. Gastroenterology, 128(5):1317-26, 2005.

Mitsui, R. Immunohistochemical characteristics of submucosal Dogiel type II neurons in rat colon. Cell Tissue Res., 340(2):257-65, 2010.

Neunlist, M.; Barouk, J.; Michel, K.; Just, I.; Oreshkova, T.; Schemann, M. \& Galmiche, J. P. Toxin B of Clostridium difficile activates human VIP submucosal neurons, in part via an IL-1beta-dependent pathway. Am. $J$. Physiol. Gastrointest. Liver Physiol., 285(5):G1049-55, 2003.

Sant'Ana, D. M.; Araújo, E. J.; Ramos, D. H.; Hermes-Uliana, C. \& Natali, M. R. Characterization of the myenteric neuronal population and subpopulation of the duodenum of adult wistar rat fed with hypoproteic chow. An. Acad. Bras. Cienc., 84(3):799-806, 2012a.

Sant'Ana, D. M.; Góis, M. B.; Zanoni, J. N.; da Silva, A. V.; da Silva, C. J. \& Araújo, E. J. Intraepithelial lymphocytes, goblet cells and VIP-IR submucosal neurons of jejunum rats infected with Toxoplasma gondii. Int. J. Exp. Pathol., 93(4):279-86, 2012b.

Sant'Ana, D. M.; Miranda Neto, M. H.; de Souza, R. R. \& Molinari, S. L. Morphological and quantitative study of the myenteric plexus of the ascending colon of rats subjected to proteic desnutrition. Arq. Neuropsiquiatr., 55(4):687-95, 1997.

Santer, R. M. Survival of the population of NADPH-diaphorase stained myenteric neurons in the small intestine of aged rats. J. Auton. Nerv. Syst., 49(2):115-21, 1994.
Savidge, T. C.; Newman, P.; Pothoulakis, C.; Ruhl, A.; Neunlist, M.; Bourreille, A.; Hurst, R. \& Sofroniew, M. V. Enteric glia regulate intestinal barrier function and inflammation via release of Snitrosoglutathione. Gastroenterology, 132(4):1344-58, 2007.

Sayegh, A. \& Ritter, R. C. Morphology and distribution of nitric oxide synthase-, neurokinin-1 receptor-, calretinin-, calbindin-, and neurofilament-M-immunoreactive neurons in the myenteric and submucosal plexuses of the rat small intestine. Anat. Rec. A Discov. Mol. Cell. Evol. Biol., 271(1):209-16, 2003.

Schabadasch, A. Intramurale Nervengeflechte des Darmrohrs. Z. Zellforsch, 10:320-85, 1930.

Scherer-Singler, U.; Vincent, S. R.; Kimura, H. \& McGeer, E. G. Demonstration of a unique population of neurons with NADPHdiaphorase histochemistry. J. Neurosci. Methods, 9(3):229-34, 1983.

Sousa, N. B. Estudo Morfoquantitativo Histoquímico e Ultraestrutural do Plexo Submucoso do Tubo Digestivo do Calomys Callosus. Tese Doutorado em Ciências Morfofuncionais. São Paulo, Instituto de Ciências Biomédicas, Universidade de São Paulo, 1994.

Timmermans, J. P.; Hens, J. \& Adriaensen, D. Outer submucous plexus: an intrinsic nerve network involved in both secretory and motility processes in the intestine of large mammals and humans. Anat. Rec., $262(1): 71-8,2001$

Toumi, F.; Neunlist, M.; Cassagnau, E.; Parois, S.; Laboisse, C. L.; Galmiche, J. P. \& Jarry, A. Human submucosal neurones regulate intestinal epithelial cell proliferation: evidence from a novel co-culture model. Neurogastroenterol. Motil., 15(3):239-42, 2003.

Vivas, L. A.; Jamel, N.; Refinetti, R. A.; Silva, L. F.; Rodrigues, L. V.; Silva, P. C. \& Schanaider, A. Anesthetic experimental device for small animal. Acta Cir. Bras., 22(3):229-33, 2007.

Weber, E.; Neunlist, M.; Schemann, M. \& Frieling, T. Neural components of distension-evoked secretory responses in the guinea-pig distal colon. J. Physiol., 536(Pt. 3):741-51, 2001.

Young, H. M. \& Ciampoli, D. Transient expression of neuronal nitric oxide synthase by neurons of the submucous plexus of the mouse small intestine. Cell Tissue Res., 291(3):395-401, 1998.

Zanesco, M. C. \& Souza, R. R. Morphoquantitative study of the submucous plexus (of Meissner) of the jejunum-ileum of young and old guinea pigs. Arq. Neuropsiquiatr., 69(1):85-90, 2011.

\section{Corresponding author: \\ Marcelo Biondaro Góis \\ Department Morphological Sciences \\ State University of Maringa \\ Av. Colombo, 5790 \\ Zona 07, Zip code 87020-900 Maringá - PR, \\ BRAZIL}

E-mail: marcelobiondaro@gmail.com

Received:16-10-2015

Accepted: 20-09-2016 